DOI: $10.5216 / \mathrm{hr} . v 15 \mathrm{i} 2.14234$

\title{
RITUAIS E SÍMBOLOS DE PODER NA VISITA AOS REIS \\ DA BÉLGICA AO BRASIL, 1920
}

Luciana Pessanha Fagundes* Ipfagundes392@hotmail.com

Resumo: Este trabalho analisa alguns momentos da visita dos reis da Bélgica ao Brasil no ano de 1920. São eles: o período anterior à chegada dos reis e as recepções aos reais visitantes nas cidades do Rio de Janeiro, Belo Horizonte e São Paulo. A escolha desses momentos explica-se pela ampla participação do público nestas ocasiões, descritas como eventos apoteóticos e emotivos. Nosso objetivo é realizar uma leitura de tais momentos, através das descrições publicadas na imprensa, e do material imagético nelas veiculado, atentando para as representações e os símbolos de poder associados aos reais visitantes e à República brasileira.

Palavras-Chave: Visita, reis belgas, primeira república.

Em uma ensolarada manhã de domingo, dia 19 de setembro de 1920, chegavam à cidade do Rio de Janeiro Alberto I e Elisabeth da Bélgica. Os soberanos belgas ficaram na cidade até o dia 28 de setembro, quando partiram para o interior do estado e visitaram as cidades de Petrópolis e Teresópolis. Foram também recebidos nos estados de Minas Gerais e São Paulo. Enquanto visitavam a capital paulista, desembarcava em 5 de outubro, no Rio de Janeiro, o príncipe Leopoldo, que prontamente juntou-se a seus pais em São Paulo. Voltando para a cidade do Rio de Janeiro no dia 13 outubro, os soberanos e o príncipe partiriam para a Bélgica no dia 16 do mesmo mês.

* Doutoranda no Programa de Pós-Graduação em História, Política e Bens Culturais do Centro de Pesquisa e Documentação Contemporânea do Brasil do CPDOC/FGV. Bolsista da Fundação de Amparo à Pesquisa do Estado do Rio de Janeiro. 
Dois fatores são apontados como sendo cruciais para determinar a vinda do rei Alberto ao Brasil: a visita do recém-eleito presidente Epitácio Pessoa à Bélgica em maio de 1919, e o apoio brasileiro dado aos belgas durante a Primeira Guerra Mundial, quando o primeiro protesto contra a invasão alemã foi feito pelo Brasil, pelo parlamento brasileiro nos discursos de Ruy Barbosa e Irineu Machado. Ao analisar a documentação sobre a visita, contida nos arquivos do Ministério das Relações Exteriores ${ }^{1}$, além da própria imprensa ${ }^{2}$, é perceptível que a vinda do rei se dá em retribuição a esses dois fatores, sendo possível caracterizá-la como um momento crucial para o estabelecimento de uma aliança entre duas sociedades, tanto de cunho econômico quanto moral. Assim, a visita do rei Alberto serviu como uma propaganda da amizade belgo-brasileira, possuindo também um caráter econômico muito forte, preenchendo os interesses dos industriais e financistas belgas, voltados não apenas para o mercado brasileiro, mas, principalmente, para os recursos minerais do país (DI MAMBRO, 2000).

Este artigo foca sua análise em momentos específicos da visita, como o período anterior à chegada dos reis, e as recepções dos reis nas cidades do Rio de Janeiro, Belo Horizonte e São Paulo. A escolha desses momentos, e não de outros, explica-se pela ampla participação do público nestas ocasiões, descritas como eventos, apoteóticos e bastante emotivos. Pretende-se realizar uma leitura dos eventos, através das descrições e do material imagético publicados na imprensa, no sentido de analisar as representações e os símbolos de poder associados aos reais visitantes e à República brasileira, e também para a forma como é construído todo o ritual de recepção aos visitantes nas capitais brasileiras.

A análise de rituais e símbolos de poder como elemento essencial de um sistema político poder ser observada em trabalhos antigos, como o de Marc Bloch sobre o milagre de cura dos reis, onde o historiador repensa a política aliada ao maravilhoso, ressaltando a importância de atentar para as relações entre política, rituais e símbolos, na compreensão de fábulas e crenças que floresceram em torno das casas principescas (BLOCH, 1993). Todavia, o estudo de tal objeto estava longe de ser usual, o próprio Marc Bloch aponta, em sua introdução, ter sido considerado "vítima de uma curiosidade bizarra" (BLOCH, 1993 p. 43), devido à escolha do tema. A publicação da obra pioneira de Bloch, em 1924, não seria então um ponto de virada para a história política, relegada a um papel periférico pela historiografia do Annales. Apenas em um momento posterior, a história política apareceria regenerada, renascida, com a ampliação das fronteiras que delimitavam o campo político, incorporando novos objetos de estudo (LE GOFF], [s.d]; FERREIRA, 1992; RÉMOND, 2003). 
Qual a importância de trazer essa abordagem sobre o maravilhoso na política para o momento em questão? Iniciando com o trabalho de Bloch, apontamos já para outras direções que se mesclam em novos olhares para a análise de um momento peculiar. Afinal, Alberto I era o primeiro monarca a visitar a América do Sul, e o Brasil não via uma testa coroada desde 1889, quando mandara para o exílio seu imperador. Partindo desse ponto, torna-se mais clara a visita belga, possibilitando, desta forma, vislumbrar respostas para algumas perguntas que aparentemente são banais: $\mathrm{O}$ que havia de tão especial na visita desses personagens ao Brasil? Por que houve tamanha mobilização, tamanho alvoroço?

Utilizando-se do instrumental fornecido por Durkheim (DURKHEIM, 2000), a análise de Edward Shils e Michael Young sobre a coroação da rainha Elisabeth II fornece algumas pistas. Ao procurar explicar o entusiasmo popular em torno da coroação, Shils ressalta as características de ritual religioso, de experiência coletiva e não individual, presentes na coroação, momento em que certos valores são suscitados, como a família unida à grande família nacional através da monarquia, ou seja, no momento da coroação há concordância em torno de certos padrões morais fundamentais.

Todavia, a análise de Shils e Young recebeu críticas por vislumbrar apenas consenso no momento da cerimônia, sem perceber que também havia conflito nesta sociedade (BIRBAUM, 1955). Entrando na discussão sobre o papel dos rituais na sociedade moderna, ressalto nesse debate o trabalho de Steven Lukes, que não deixa de lado a tradição durkheimiana, ao apontar para além do efeito do ritual como integrador social, sua função como meio cognitivo de interpretar o mundo social, ou seja, um meio de expressar e dramatizar as realidades sociais (LUKES, 1975, p. 289-308).

Este seria o ponto mais importante apontado por Lukes, ou seja, não basta a crença, mas sim a participação, o caráter performático do ritual. As pessoas que dele participam podem não ter a mesma crença, possibilitando que existam vários consensos e vários dissensos nesse momento, que devem ser compreendidos em conjunto. É sob esta perspectiva que iremos empreender uma releitura de certos episódios ocorridos durante a visita belga de 1920 .

\section{Por dentro da Visita Belga: importânCia E Significados}

As primeiras notícias sobre a visita do rei ao Brasil apareceriam já nos meses iniciais de 1920. Sobre Alberto I, o Jornal do Brasil aponta que ele se tornou um dos personagens mais admirados e respeitados do mundo, se distinguindo durante a guerra "pelo seu devotamento a pátria, espírito de sacrifício, sentimen- 
to democrático e filantrópico". Segundo o jornal, as maiores homenagens foram prestadas ao soberano "por todos os países cultos da terra em reconhecimento de suas extraordinárias virtudes” (JORNAL DO BRASIL..., 1920).

A visita seria, definitivamente, para o Correio da Manhã, "o acontecimento do ano", sendo que a figura do rei, cercada de lenda, influía "profundamente sobre a imaginação do carioca entusiasta, curioso e acolhedor" (Correio da Manhãa, Rio de Janeiro, 12 de jun. de 1920). Já o jornalista Gilberto Amado apontava o rei Alberto como a pessoa capaz de conciliar "o espírito democrático do nosso tempo com as tradições da velha casa dinástica”. A visita ao Brasil seria, então, uma ótima oportunidade para o povo brasileiro "aclamar uma das mais belas figuras morais do mundo moderno", assim como chamaria a atenção do mundo para o Brasil, para a sua "república consolidada”, para o seu progresso e prestigio (O PAIZ..., 1920). $\mathrm{O}$ artigo do jornalista serve como ponto de partida para formularmos uma pergunta crucial sobre a visita e seus preparativos. Afinal, como seriam então representados este rei moderno e a 'república consolidada' que o recebia?

Nesse sentido, uma questão importante que cerca os preparativos para a visita belga era a organização do programa. Pensar quais as recepções, passeios ou festas que seriam oferecidas ao rei belga, não seria tarefa das mais fáceis. Assim, no início de junho de 1920 foi organizada uma comissão com esse intuito, capitaneada pelo Itamaraty, cuja chefia coube a Azevedo Marques, Ministro das Relações Exteriores. O trabalho da comissão era voltado, principalmente, para a capital federal, sendo a programação entregue ao presidente em 2 de agosto de 1920, sob o título "Programa das Homenagens aos reis no Brasil", mas que compreendia somente a programação relativa à capital federal (Arquivo "A visita dos Reis da Bélgica”).

Enfim, decidida a programação do evento, a preocupação das autoridades voltou-se para a organização da capital federal. Carlos Sampaio, prefeito da cidade no período, foi o encarregado de limpar, corrigir os calçamentos, lavar as estátuas, podar as árvores e consertar as avenidas. Este é um dos aspectos que deve ser considerado no momento de se compreender o sucesso da chegada dos soberanos, ou seja, o cenário da capital federal.

Às vésperas da chegada dos reais visitantes, no dia 18 de setembro de 1920, o Jornal do Commercio do dia 18, publica em sua primeira página a bandeira e o brasão belga, acompanhados de fotos do rei e da rainha e do presidente Epitácio Pessoa. A imagem do rei reproduzida apresenta-o em seu uniforme de campanha (Figura 1), e será uma das imagens mais repetidas: a do rei soldado, que virá também acompanhada de cenas de sua atuação na Primeira Guerra Mundial (Figuras 2 e 3). 


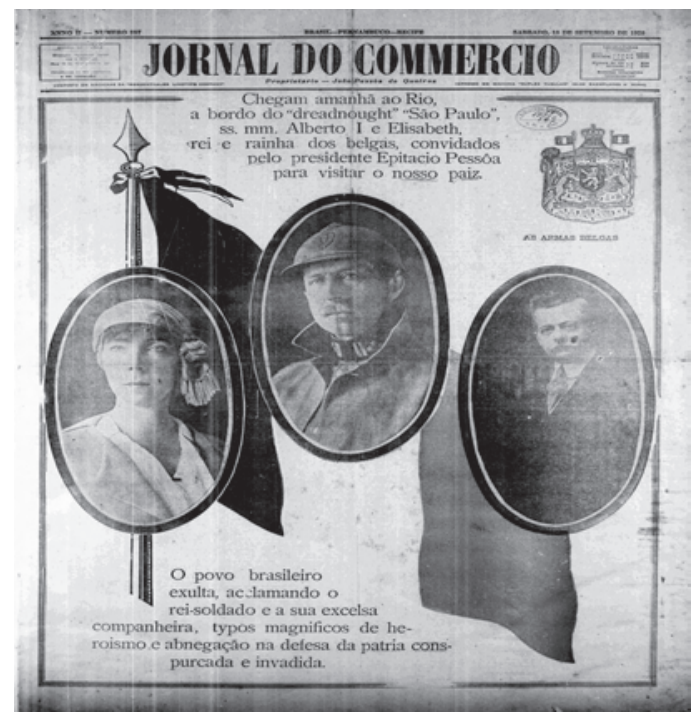

Figura 1: A chegada dos reis belgas na imprensa carioca Fonte: Jornal do Commercio. 18.09.1920

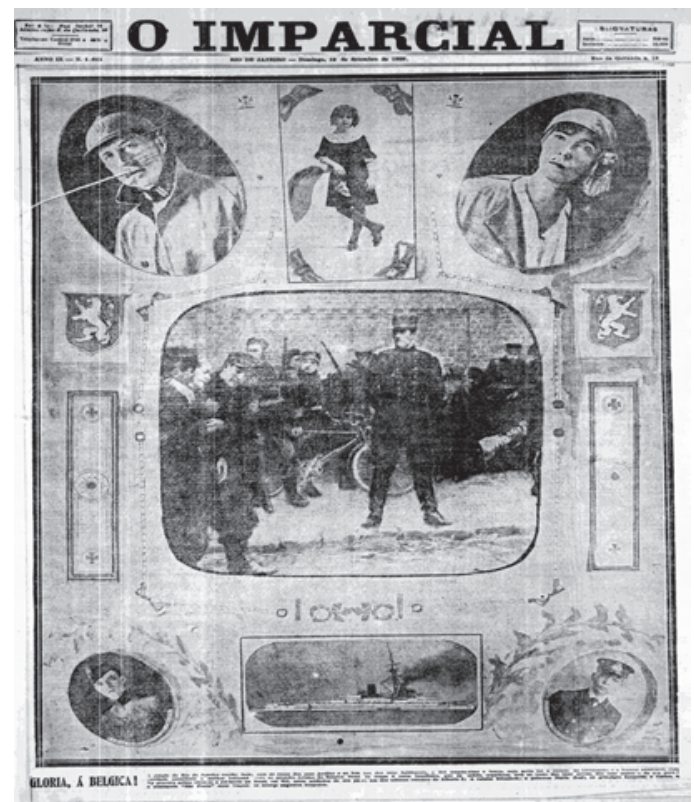

Figura 2: A família real belga e o rei do Alberto na Primeira Guerra Mundial Fonte: O Imparcial. 19.09.1920 


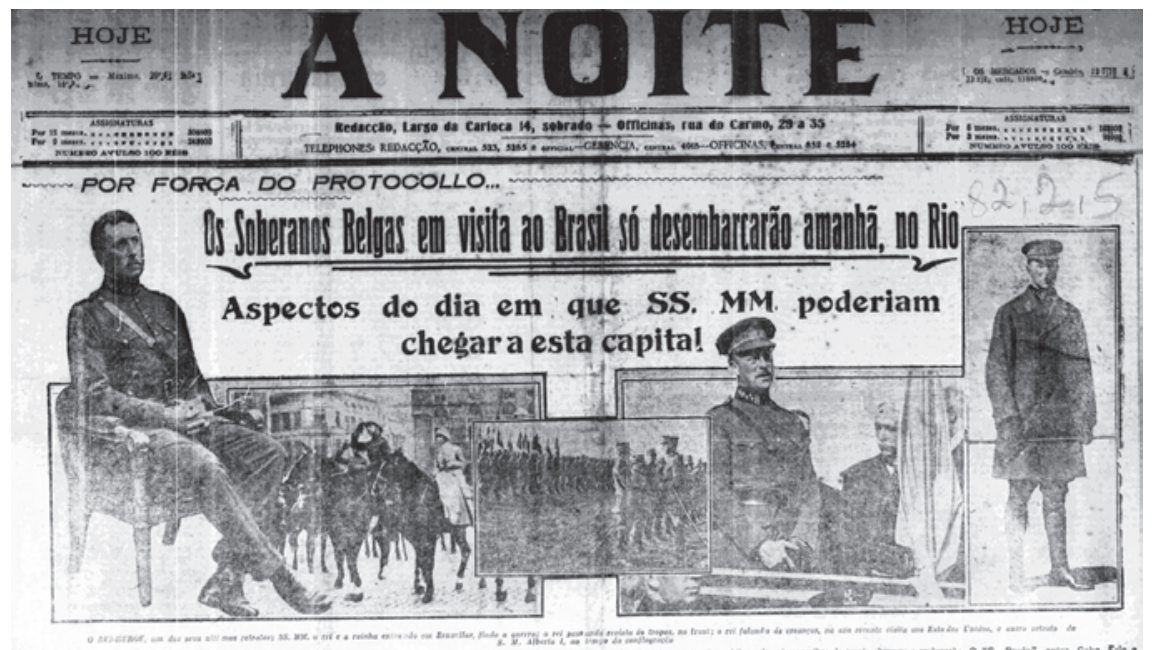

Figura 3: Rei Alberto, herói militar

Fonte: A Noite, 18.09.1920

Representando o Brasil, a imagem mais recorrente é a do couraçado S.Paulo, em que os soberanos belgas fariam sua viagem ao Brasil. A primeira página do jornal $A$ Noite segue tal padrão, publicando fotos do S. Paulo (Figura 4) e do Palácio Guanabara (Figura 7), onde os soberanos ficaram hospedados, adornados com o brasão belga e o da república brasileira. Um detalhe interessante, todavia, aparece entre as fotos da rainha e do rei. Trata-se de um desenho de um rei trajando vestes de cavaleiro medieval, que empunha sua espada contra uma águia, em cuja cabeça foi desenhado o capacete do exército alemão utilizado na Primeira Guerra (Figura 5). Era o rei-herói, retratado em sua luta contra o inimigo comum da civilização, identificado no momento com a Alemanha e seu exército.

$\mathrm{O}$ texto publicado junto às imagens apontava o evento próximo como a visita do "rei mais heróico da terra", na qual o povo brasileiro participaria não apenas por curiosidade e cortesia, mas para "assistir um espetáculo que vale por um ensinamento, por uma lição de moral e de civilismo”. A recepção que entusiasmava o Brasil, aponta o jornal, seria aquela em que o povo aclama "mesmo sem ver" os grandes soberanos belgas, cujo "o nome e a figura [...] anda reproduzida por toda a parte" (A NOITE..., 1920). O texto e a imagem publicados no jornal $A$ Noite são um exemplo da aura heróica construída em torno do personagem, bem como do valor atribuído à recepção, que aparece como uma lição de moral, de civilidade para a qual o povo conscientemente se apresenta. 

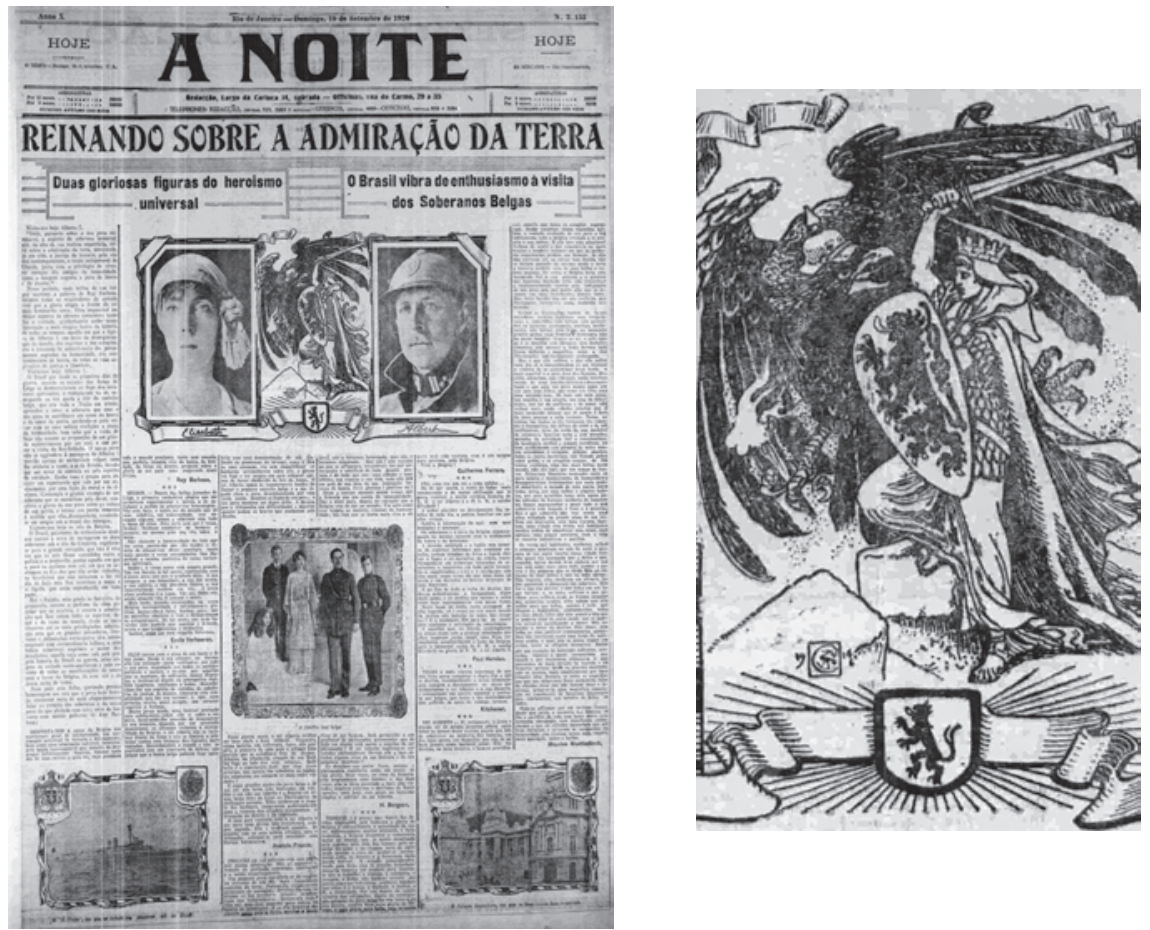

Figura 4: Homenagens aos reis belgas na primeira página do Jornal A Noite. Fonte: A Noite, 19.09.1920
Figura 5: Detalhe do desenho que separa a fotografia dos reis

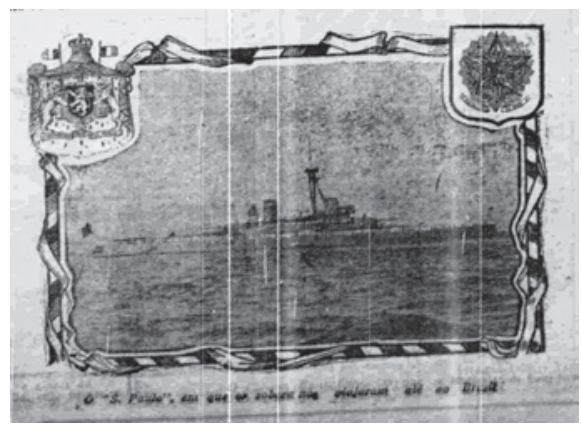

Figura 6: O couraçado S. Paulo

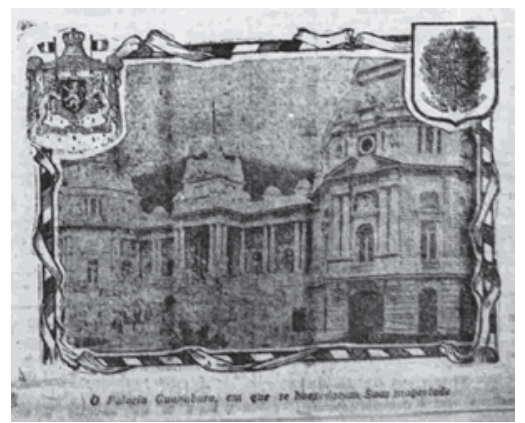

Figura 7: O Palácio de Guanabara 
Alberto I aparece também em fotografias com seu uniforme de gala, e até em trajes civis, que acompanham o texto publicado no jornal $A$ Pátria cuja coluna sobre o rei, muito propriamente intitulada "Alberto I intimo", oferece aos leitores notas sobre sua juventude, suas habilidades como mecânico, alpinista, "intrépido" cavalheiro, "yachtman”, em suma, um "audacioso sportsman”, mas também um "herói autêntico" (Figura 8). Colocada desta forma, a visita belga era, ao mesmo tempo, uma homenagem a um rei e uma "ovação" a um homem, o soldado que forneceu um exemplo "a todos os outros condutores de povos, coroados ou não", representando ainda "o mais admirável legado da realeza democrática”. Após atribuir características tão eloquentes a este personagem, o jornal visualiza na visita um significado grandioso:

O Brasil - República não poderia esperar da fortuna a visita de um Rei, primeira que tem no novo regime, mais expressiva dos sentimentos e das idéias que impressionam a sua consciência nacional (A PÁTRIA, 1920; AGENCIA AMERICANA, 1920).

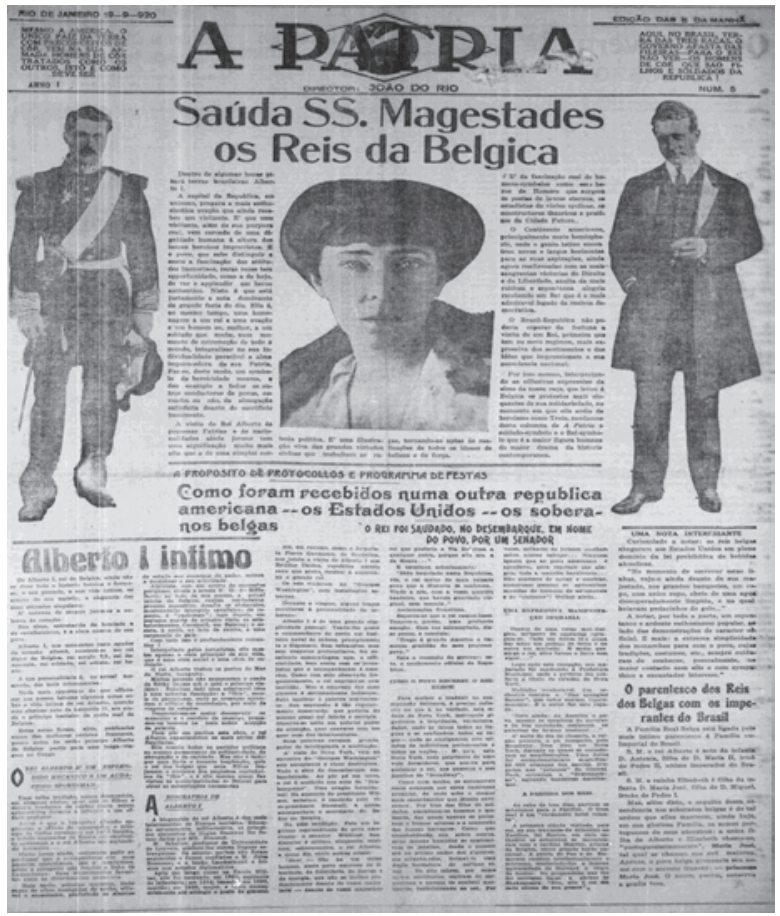

Figura 8: As várias faces do rfei pelo jornal A Pátria. Fonte: A Pátria, 19.09.1920 
Os "sentimentos" e "ideias" aplicados à pessoa do rei são identificados com a nação brasileira, que também compartilha dos valores democráticos e do espírito liberal. Percebe-se que a majestade que envolve Alberto I assemelha-se àquela já identificada, em meados do século XIX, em soberanos como Luís Felipe, que eram apresentados como figuras mais acessíveis a seus súditos, sem os acessórios mais característicos da realeza como a coroa e o cetro (BURKE, 1994.p. 213). A própria imagem de D. Pedro II, após a Guerra do Paraguai, seguiria tal modelo, com a adoção pelo imperador de uma representação mais sóbria, na figura do "monarca-cidadão", o que implicou um afastamento do ritual majestático (SCHWARCZ, 1999, p. 320-324).

Todavia, as referências à "realeza democrática", que Alberto I representa, não deixam dúvidas de que há sim uma majestade que circunda tal personagem. Ou seja, como ressaltou Clifford Geertz, apesar dos tronos, cortejos e pompas estarem fora de moda, ainda é necessário que haja uma afinidade entre os chefes políticos e a sociedade. Esta "realeza democrática" construída em torno de Alberto I não deve ser lida como uma majestade inata, mas sim como uma construção em torno de certos valores válidos a serem celebrados por uma república (GEERTZ, 1997).

A matéria de $O$ Paiz aponta claramente tal construção, ao colocar que mesmo não se tratando de uma época muito favorável aos monarcas, devido às crises que envolviam os valores políticos no mundo moderno, para o rei Alberto tal momento era uma oportunidade de se livrar "das nebulosas roupagens com que as figuras dos reis eram envolvidas pela poderosa sugestão das antigas concepções de majestade" e revelar seu verdadeiro valor.

Os reis voltam, a ser, apenas chefes das nações, e as fórmulas simbólicas da majestade só podem se tornar respeitáveis por aqueles que têm a alma forte, dos que sabem mandar, sabem combater e sabem afrontar todas as calamidades. Um desses reis modernos, que se apresentam, não como os representantes de tradições embalsamados pelo protocolo, mas como fortes personalidades representativas das suas nações, expoentes dos traços mais nobres e mais característicos dos povos de que são chefes, é, seguramente, Alberto I (O PAIZ, 1920).

Assim, não são surpreendentes as descrições de Alberto I como o "monarca moderno", um modelo de rei democrata, que a um povo "tão profundamente democrático, tão orgulhoso das tendências republicanas" como o brasileiro, muito honra ter como hóspede. Um rei que, inclusive, fornece um exemplo da "adaptação das instituições monárquicas a essas cor- 
rentes republicanas e democráticas que, para nós, no continente americano, constituem a única forma admirável de pensamento político" ( $O$ Paiz, Rio de Janeiro, 19 de set. de 1920).

Enfim, no dia 19 de setembro, a cidade do Rio de Janeiro seria o centro desta sociedade, onde, através de determinadas formas rituais, ver-se-ia pela primeira vez o tão aclamado rei da Bélgica.

\section{A ReCEPÇÃo no Rio de Janeiro}

A cidade encontrava-se enfeitada da Praça Mauá até o Palácio Guanabara com as bandeiras do Brasil e da Bélgica. Os edifícios públicos e particulares ostentavam em suas fachadas as bandeiras belga e brasileira, os cinemas colocaram painéis com retratos dos soberanos circundados com saudações entusiastas. Enfim, um verdadeiro display of flags ${ }^{3}$ apresentava-se por todo o trajeto que seria percorrido pelo cortejo.

Especial atenção seria destinada ao controle da população da cidade, os dias próximos da chegada são marcados por reuniões constantes entre o chefe de polícia, o ministro da justiça e o presidente da república, que tinham como objetivo definir o policiamento especial da cidade. Assim, ao longo do trajeto que seria percorrido pelo cortejo, tropas da Marinha, do Exército e da Polícia Militar formariam duas colunas desde o Cais do Porto até o Palácio Guanabara, justamente para "garantir em todo o percurso o bom arrumamento popular, e preservar o séquito de invasões inconvenientes" (CORREIO DA MANHÃ, 14 de set. de 1920).

Pouco antes das 13 horas, começaram a chegar à Avenida as tropas do Exército, formando alas por onde passaria o cortejo real. A passagem da Escola de Guerra em direção à Praça de Mauá (Figura 9) foi registrada pelo Jornal do Brasil e publicada em sua edição do dia seguinte, em que relatava detalhadamente a chegado dos soberanos. A partir dessa pequena imagem - publicada na $5^{\text {a }}$ página do jornal, ocupando o centro das duas primeira colunas - e de outra publicada no jornal $A$ Razão (Figura 10, $1^{\text {a }}$ página, 2 duas últimas colunas ao centro da página), podemos ter uma noção do lugar estabelecido para o público e para o desfile da comitiva.

As bandas de música, formadas à esquerda das tropas, aguardavam a passagem dos soberanos para executarem o hino belga e brasileiro (JORNAL DO BRASIL, 1920). O público ocupava seus lugares, e por entre a massa de gente, abundavam os "camelots", vendendo toda espécie de objetos referentes à chegada dos soberanos belgas, desde medalhas com a efígie do rei herói (Figura 11), até leques com o retrato do personagem. Vários são os artigos 
produzidos, cujo tema é a visita dos reis, e também a própria imagem do rei é utilizada para fazer propaganda de produtos nacionais (Figura 12).

Além da mercantilização da imagem do rei, perceptível nesses anúncios, cabe ressaltar, em relação às medalhas, a justificativa apresentada para o seu uso, presente no próprio texto da propaganda, onde lê-se: "É preciso que a sua recepção não se caracterize somente por manifestações ruidosas. Para mostrarmos ao Rei o quanto lhe queremos. Devemos usar a sua efígie como ornamento" (CORREIO DA MANHÃ, 1920). A preocupação com as manifestações do público aparece mais vezes, procurando-se adequá-las ao tipo de visitante que seria recebido, associando-as inclusive ao que seria o símbolo dessa forma mais "civilizada" de receber o rei, ou seja, com o uso de tal medalha.

Também era possível comprar postais comemorativos do evento, editados pelos Srs Theophilo Carinhas \& C., que traziam letra e música do hino brasileiro e belga, assim como os retratos dos soberanos belgas, do presidente da república (JORNAL DO BRASIL, 1920).

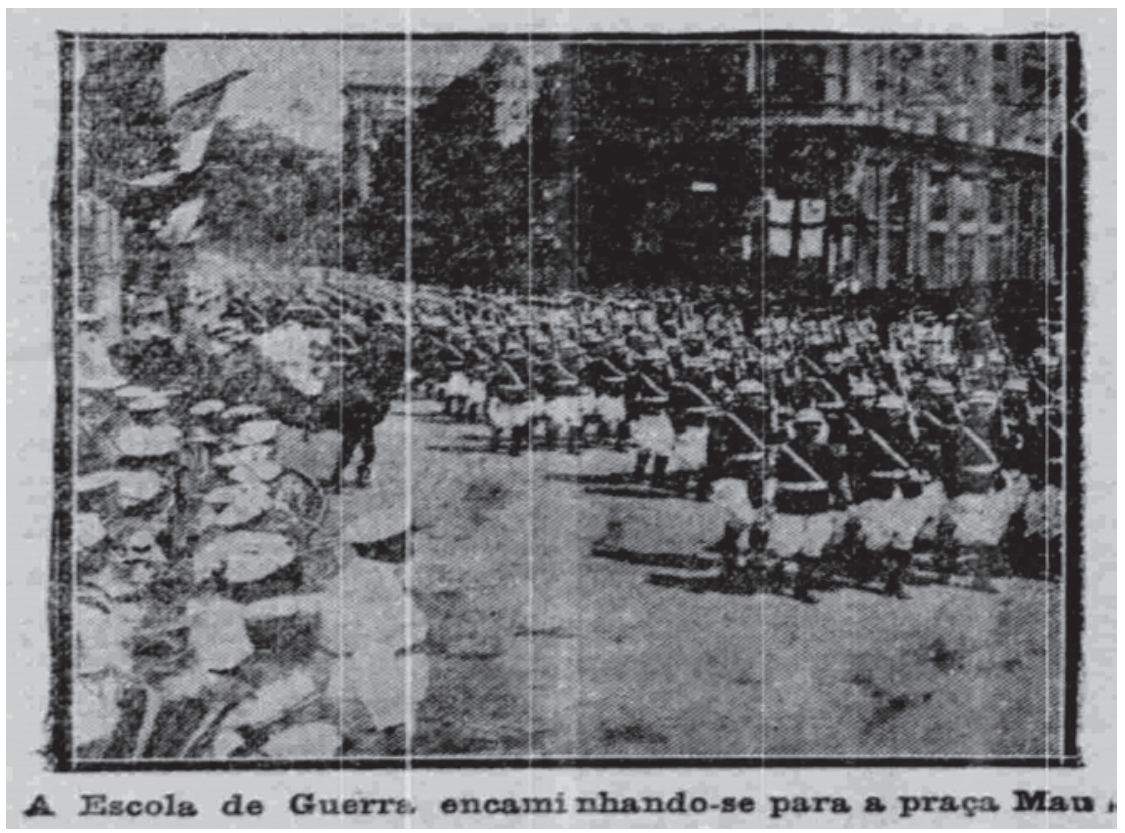

Figura 9: Desfile militar na recepção do Rio de Janeiro Fonte: Jornal do Brasil, 20.09.1920 


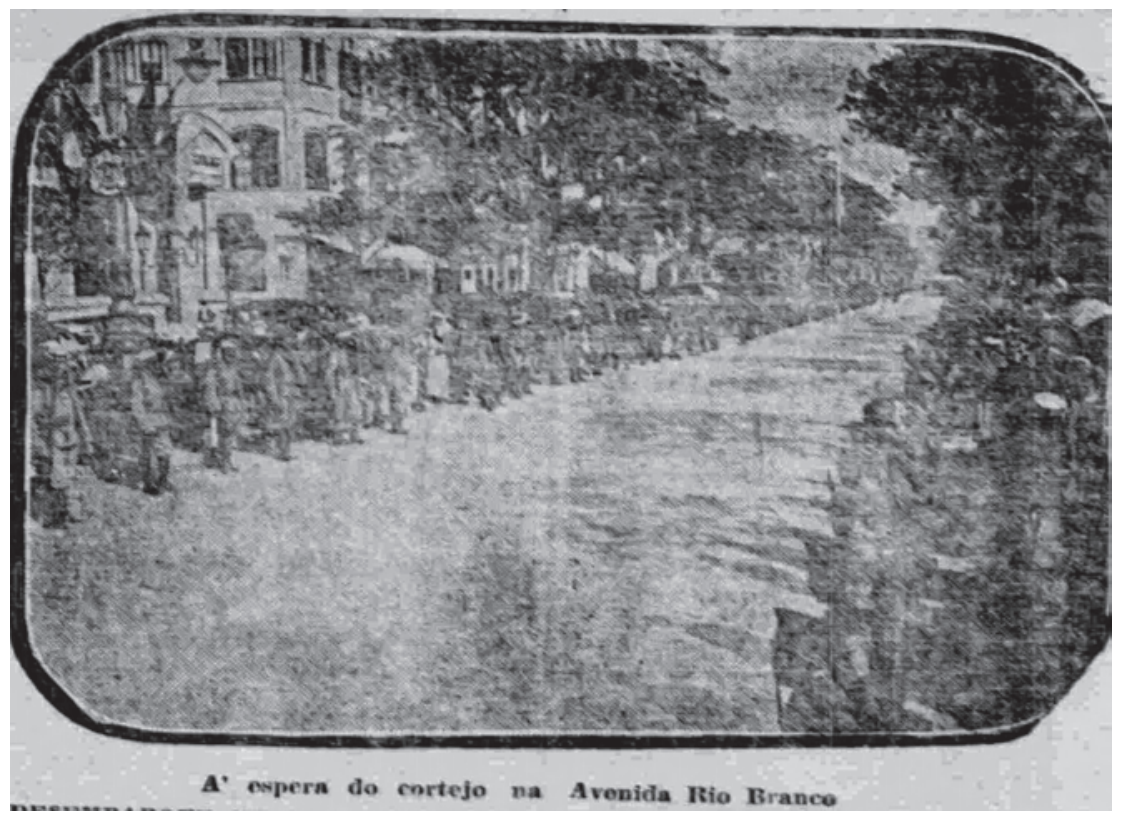

Figura 10: O espaço da Avenida Rio Branco organizada para receber o cortejo Fonte: A Razão, 20.09.1920

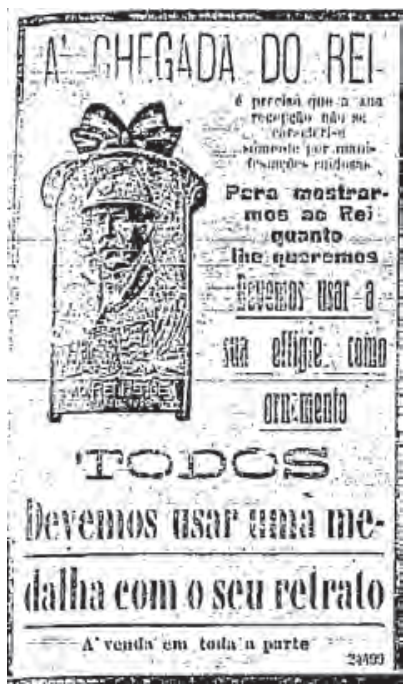

Figura 11: Exemplo de souvenir produzido para a visita

Fonte: Correio da Manhã, 19.09.1920

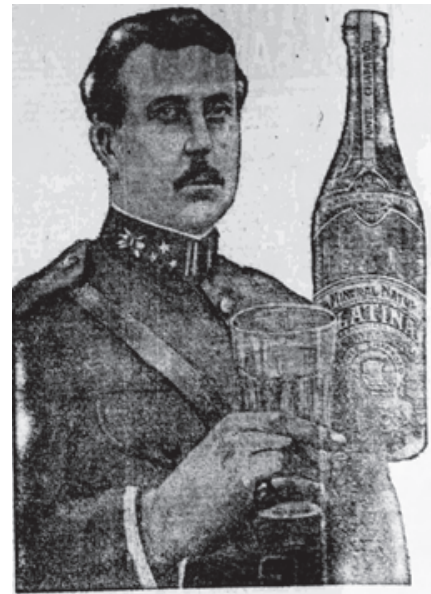

Sua Majestade reconhece ser a "PLATINA" a melhor agu.. de mesa.

Figura 12: Anúncio publicitário

Fonte: Jornal Edição de São Paulo, 05.10.1920

Hist.R., Goiânia, v. 15, n. 2, p. 393-419, jul./dez. 2010 
Por volta das 13 horas, o S.Paulo adentrou a Baía de Guanabara, ao som dos canhões das fortalezas do Leme, São João, Santa Cruz e Lage, e aportou em frente à Praça Mauá, recebendo a bordo o presidente Epitácio Pessoa, sra. e senhorita Epitácio Pessoa, Azevedo Marques, Ministro das Relações Exteriores, Raul Soares, Ministro da Marinha, e Robys de Schneidauer, chefe da legação belga no Brasil. Após as apresentações, organizou-se o cortejo. No primeiro carro, tomaram lugar o rei Alberto e o presidente Epitácio Pessoa, no segundo a rainha Elisabeth e sra. Mary Pessoa, seguindo-se os outros carros da comitiva, iniciava-se o grande cortejo em direção ao Palácio Guanabara.

A recepção ficou marcada como uma "data memorável", segundo a Gazeta de Notícias, pois nunca o povo "tão reservado nas externações de suas alegrias ou de suas dores", expandiu-se "mais francamente, mais alegremente, mais entusiasticamente, para dizer a um hospede ilustre o amor com que o acolhíamos" (GAZETA DE NOTICIAS; AGENCIA AMERICANA, 1920). Tal observação do jornal traz à tona algumas questões interessantes: Que público é esse que foi receber o rei- herói? Como ele é representado nos discursos textual e imagético publicados nos jornais? Qual o lugar que deveria ocupar no ritual da recepção?

O público que aparece representado nas páginas dos jornais cariocas era composto por todas as classes sociais, "senhoras da nossa mais fina sociedade, homens que representam a mentalidade, a posição social e a riqueza deste país foram associar-se ao coro popular", bem como o operariado brasileiro, observou o jornal O Paiz (1920).

Uma característica também ressaltada pelo Jornal do Brasil ao colocar que "todas as classes sociais vieram estender-se, em alas, do cais do desembarque ao Palácio Guanabara, formando a mais bela das correntes humanas" (JORNAL DO BRASIL, 1920). Na descrição do Correio da Manhã, era possível observar a multidão de senhoras e senhoritas que, "desafiando os incômodos das festas populares", vieram admirar os soberanos. O povo "se conduzia cavalheirescamente, numa demonstração clara da consciência que tinha daquilo que ele era no momento: uma família honrada com uma visita, digna do maior apreço", um comportamento que representava, segundo o jornal, "as nossas tradições de respeito e ordem" (CORREIO DA MANHÃ, 1920).

É perceptível uma descrição repleta de elogios ao comportamento da massa popular, que, como uma família civilizada, ciente de seus deveres cívicos, compareceu para receber o seu real visitante. Assim como é claro o aspecto unificador e integrador da recepção em torno dos visitantes. A recepção carioca aos reis belgas possuía inúmeros elementos para se constituir 
em um grande sucesso e, de uma forma geral, atingiu as expectativas, apesar de alguns aspectos contraditórios serem identificados, como a atuação da polícia, delimitando o espaço desse público, ou seja, as ações 'espontâneas' de uma população tão civilizada, educada. A crítica, expressa nos jornais $A$ Pátria e $A$ Razão, apontou que a ação da polícia durante a recepção causou certo "constrangimento nas expansões do povo" (A PÁTRIA, AGENCIA AMERICANA, 1920). O jornal $A$ Razão também identificou nas medidas excessivas da polícia uma "ofensa a polidez e a boa educação do nosso povo, tão sensato, ordeiro e cavalheiresco", concorrendo para que as manifestações perdessem muito do seu brilho e da sua grandiosidade. Os reis mereciam que para sua recepção o "governo e o povo do Brasil se confundissem em uma só entidade", pois a visita é feita à Nação Brasileira. O que os exageros das precauções policiais não permitiram, ficando claro aos olhos dos soberanos a "cisão entre governantes e governados", ou seja, "a população estava agindo por conta própria, fazendo timbre em evidenciar o seu divorcio com a administração do país" (A RAZÃO; AGENCIA AMERICANA, 1920).

A recepção poderia ser um triunfo, aponta o jornal, se não fossem as medidas policiais, a intervenção do governo, no sentido de "dosar as expansões populares", "produziu um arrefecimento". Exceto pelos dias de carnaval, a cidade nunca teve tanto movimento, o "povo suportou corajosamente o sol e o calor tremendos que reinaram", tudo isso poderia fazer da recepção uma apoteose e um deslumbramento, o que não foi possível, conclui o jornal, pois, o povo ficou dentro de "quadrado militar" (A RAZÃO; AGENCIA AMERICANA, 1920).

Faltou também a inclusão de um importante personagem, Rui Barbo$\mathrm{sa}^{4}$. A ausência deste personagem criou um "vácuo" na cerimônia, observou o jornal O Imparcial (O IMPARCIAL; AGENCIA AMERICANA, 1920).

Muito presente nas descrições, o público tão aclamado nas descrições dos jornais não teria a mesma representatividade nas imagens publicadas da recepção. O público aparece representado, antes ou depois da passagem do cortejo, em imagens pequenas, com exceção da publicada na primeira página da Gazeta de Notícia, que ocupava 6 de suas 8 colunas e praticamente metade da página (Figura 13). Abundam, nesse sentido, imagens do rei e de Epitácio Pessoa, da entrada do cortejo na Avenida Rio Branco e dos soberanos sendo recebidos no Palácio Guanabara. 


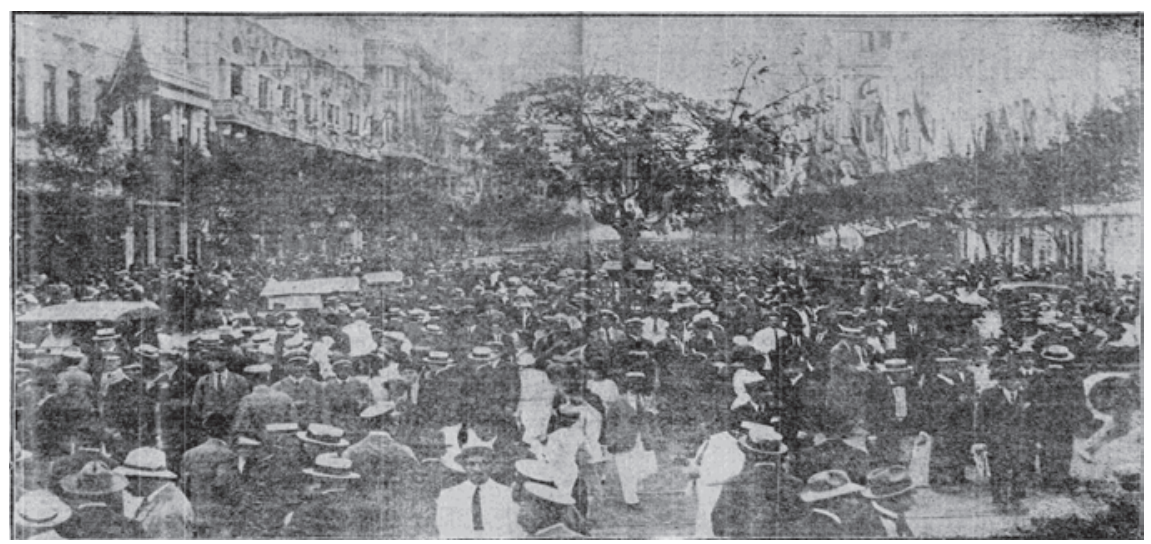

Figura 13: Mutirão na Avenida Rio Branco, após a passagem dos reis Fonte: Gazeta de Notícias 20.09.1920

As Recepções em Belo Horizonte e São Paulo

As recepções dos soberanos belgas nas outras cidades brasileiras não apresentariam elementos muito diferentes dos presentes na capital: cortejos, hinos, multidão. Entretanto, mesmo que as recepções se tornassem repetitivas, cada lugar apresentaria uma especificidade, que acabou sendo ressaltada. Assim, deve-se apontar, primeiramente, algumas pequenas diferenças na preparação da visita a esses estados, especialmente sua relação com a comissão formada com esse intuito, estabelecida na capital federal.

Na organização da programação para São Paulo, é possível observar a maior participação do Itamaraty, como noticiou a imprensa carioca, o próprio presidente do estado paulista, Washington Luís, apresentou ao presidente Epitácio Pessoa seu desejo de que o governo federal organizasse as homenagens paulistas aos reis belgas (CORREIO DA MANHÃ, 1920). Já em relação a Minas Gerais, verificamos o contrário, poucas são as referências às homenagens mineiras no Itamaraty, e não há comentários sobre tal articulação entre o presidente do estado, Artur Bernardes, e Epitácio. No caso, tal diferença pode ser explicada pelos arranjos políticos que marcaram a última eleição presidencial, em que São Paulo se opôs à candidatura do senador paraibano, apoiada por Minas Gerais e do Rio Grande do Sul ${ }^{5}$. Nesse sentido, a articulação em conjunto com o governo federal para organização das homenagens paulistas aos belgas pode ser interpretada como uma forma de aproximação desse governo com o executivo federal.

Em relação às recepções aos reis belgas em outras cidades brasileiras, visualizamos também, que uma comparação crítica entre elas, possibilita a 
formulação de críticas à imagem de um povo unido, propalada pela recepção no Rio de Janeiro, possibilitando inclusive a percepção de certos regionalismos, e da utilização desses eventos como forma de auto-afirmação dessas comunidades perante um todo.

Na recepção planejada em Belo Horizonte, os soberanos desembarcaram na Estação de Ferro Central da capital mineira, onde foram recebidos pelo presidente do Estado, Artur Bernardes, o prefeito de Belo Horizonte, Afonso Vaz de Melo, secretários do governo e grande multidão. Após o desembarque, foi organizado um cortejo ao som hino belga e brasileiro, dirigindo-se os soberanos para o palácio do governo, onde ficaram hospedados. Em frente à estação, formaram a Força Pública do Estado e o $3^{\circ}$ batalhão da força federal (A NOITE, 1920).

Sobre as impressões da chegada dos reis na capital mineira, vale ressaltar que nossa análise foi realizada com o material publicado na imprensa carioca. Nesse caso, as descrições sobre o evento são praticamente idênticas, pois os jornais reproduziam as notícias enviadas pela Agência Americana. Poucas foram as imagens da recepção veiculadas, sendo publicadas algumas no jornal O Imparcial, (O Imparcial. Rio de Janeiro; 5 de out. Agencia Americana, 1920), que retratam as tropas em continência à passagem do cortejo pela Avenida Amazonas (Figura 14), e o carro onde desfilou o rei, acompanhado do presidente do estado mineiro, Arthur Bernardes (Figura 15).

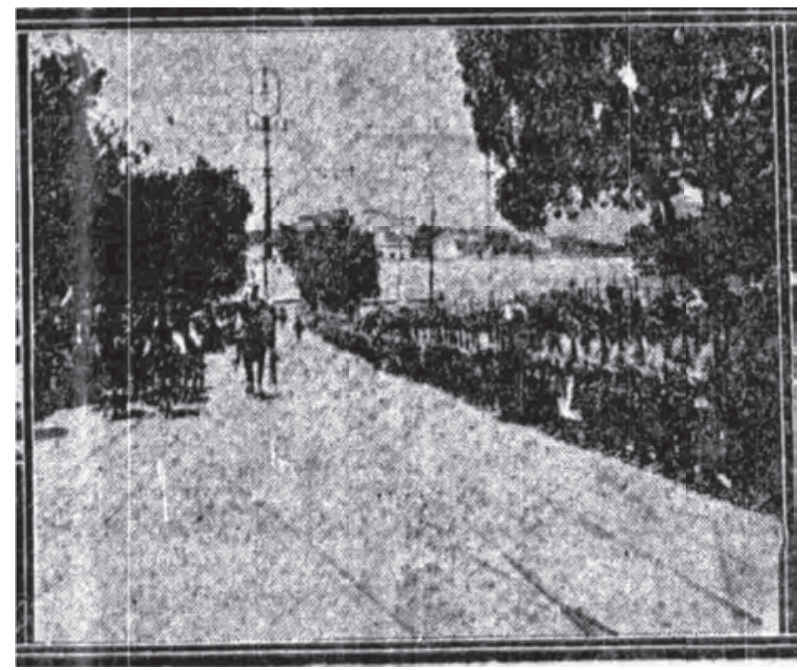

Figura 13: $\mathrm{O}$ rei em Belo Horizonte

Fonte: O Imparcial, 05.10.1920

Hist.R., Goiânia, v. 15, n. 2, p. 393-419, jul./dez. 2010 


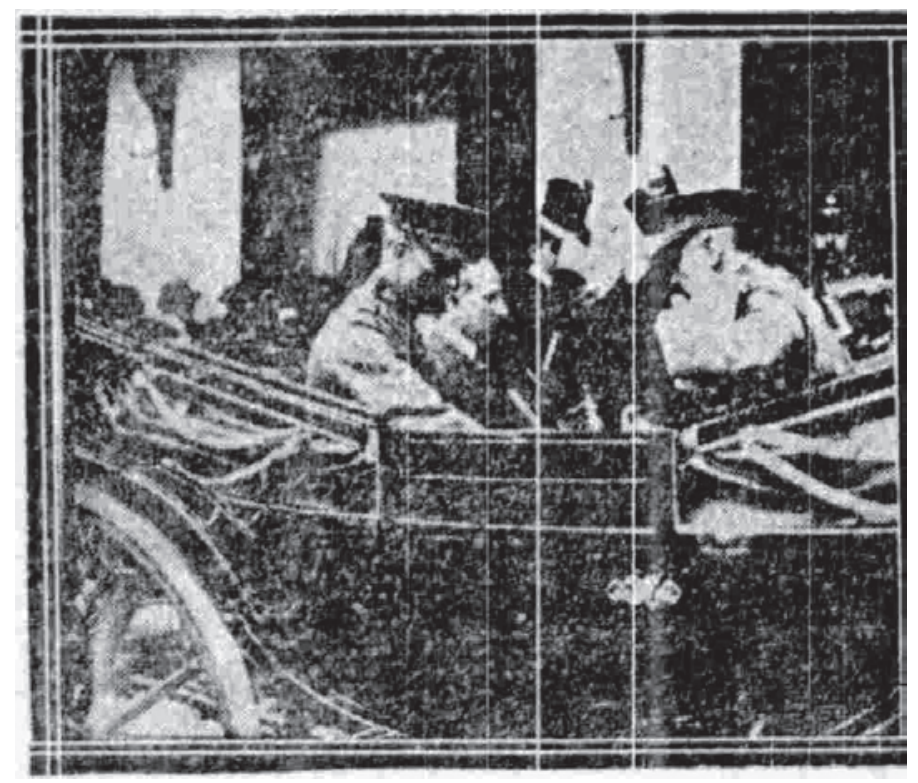

Figura 15: O cortejo em Belo Horizonte

Fonte: O Imparcial, 05.10 .1920

As impressões se assemelham àquelas observadas no Rio de Janeiro, no entanto, cabe colocar uma pequena alusão às características do povo mineiro feita pelo jornal A Pátria. Ao elogiar as aclamações "memoráveis e entusiásticas" que receberam os soberanos em Minas, o jornal aponta também que o povo mineiro seria "esquivo a manifestações públicas", no entanto, tal característica não o teria impedido de manifestar seu "carinho e de respeito aos gloriosos soberanos belgas" ( $A$ Pátria. Rio de Janeiro; 03 de out. Agencia Americana, 1920). Os periódicos cariocas fariam também um esforço para identificar a relevância da visita dos soberanos a Minas Gerais, que era encontrada, sobretudo, em suas riquezas minerais.

O jornal A Tribuna aponta que os reis iriam apreciar em Minas Gerais "as belíssimas montanhas verdes de que a natureza dotou o solo brasileiro"; "os enormes campos" deliciando-se "a cada passo, dos lindos quadros panorâmicos, que Minas, o glorioso berço de Tiradentes sabe possuir". Era reconfortante, observou o jornal, "a hospitalidade gentil que o povo mineiro sabe dar" e em um "ato natural, rende homenagem a seus hospedes, levando a Suas Majestades uma prova do amor que cada peito brasileiro guarda pelo belga, [...] seus os magnânimos e heróicos reis da Bélgica" (A TRIBUNA; AGENCIA AMERICANA, 1920). 
Em uma impressão geral sobre a viagem em Minas Gerais, o jornal Correio da Manhã ressalta que a viagem ao estado seria o momento em que soberanos aproveitariam para ver:

[...] a grandeza de um mundo novo, onde rebentam milagres de seiva e fartura todos os recursos virtuais da natureza. As vistas reais vão fixar-se em montanhas de ferro, incontrastáveis pela opulência com qualquer das da Europa que fizeram, com as jazidas de carvão, inferiores as nossas em numero, a emancipação industrial de tantas nações. Sua majestade verá o ouro apanhado facilmente nos cascalhos dos rios, e as cordilheiras de mármore, e um solo de aptidões formidáveis, estendido num cenário sem fim, que se oferece as mais estranhas culturas (CORREIO DA MANHÃ, 1920).

O rei voltaria para Europa com ótimas impressões, ao vislumbrar "um celeiro habilitado a suprir as deficiências da economia universal", sendo que a situação de desequilíbrio que reinava na economia européia favorecia o Brasil, gerando uma oportunidade única que "não nos aparecerá duas vezes", ressalta o Jornal do Commércio (JORNAL DO COMMERCIO; AGENCIA AMERICANA, 1920). A questão da exploração do minério de ferro estava na ordem do dia, com a importância da indústria siderúrgica ressaltada na Grande Guerra (MOTTA, 1992), e a visita do rei Alberto consolidou a criação da Companhia Siderúrgica Belgo-Mineira, fruto de um consórcio com um grupo belga-luxemburguês e que consistiu na compra e ampliação de uma pequena usina já existente (SILVA, 1997.p. 24).

Ainda em Minas, um episódio interessante chamaria a atenção dos jornais. Durante uma excursão em automóvel pelo interior mineiro, a rainha manifestou o desejo de conhecer o interior da casa mineira. Entrou então, "inesperadamente", na residência do coronel Joaquim José da Silva, percorrendo todos os aposentos, servindo-se de um copo de leite e café (A NOITE, 1920).

Enfim, encerradas as aclamações em Minas Gerais, o próximo destino dos reis seria o próspero Estado de São Paulo.

A análise da recepção em São Paulo tornou-se mais rica pela utilização de algumas edições dos jornais paulistas, inclusive de antes da chegada dos soberanos ao estado, incluídas no álbum da Agência Americana. Assim como a imprensa carioca, os jornais paulistas publicam grandes reportagens sobre os soberanos e a Bélgica (Figura 16). Todavia, o que mais interessa acompanhar são as expectativas com a recepção, as especulações de como os soberanos deveriam ser recebidos e o que representava para aquela comunidade a visita, instigando sua definição. 


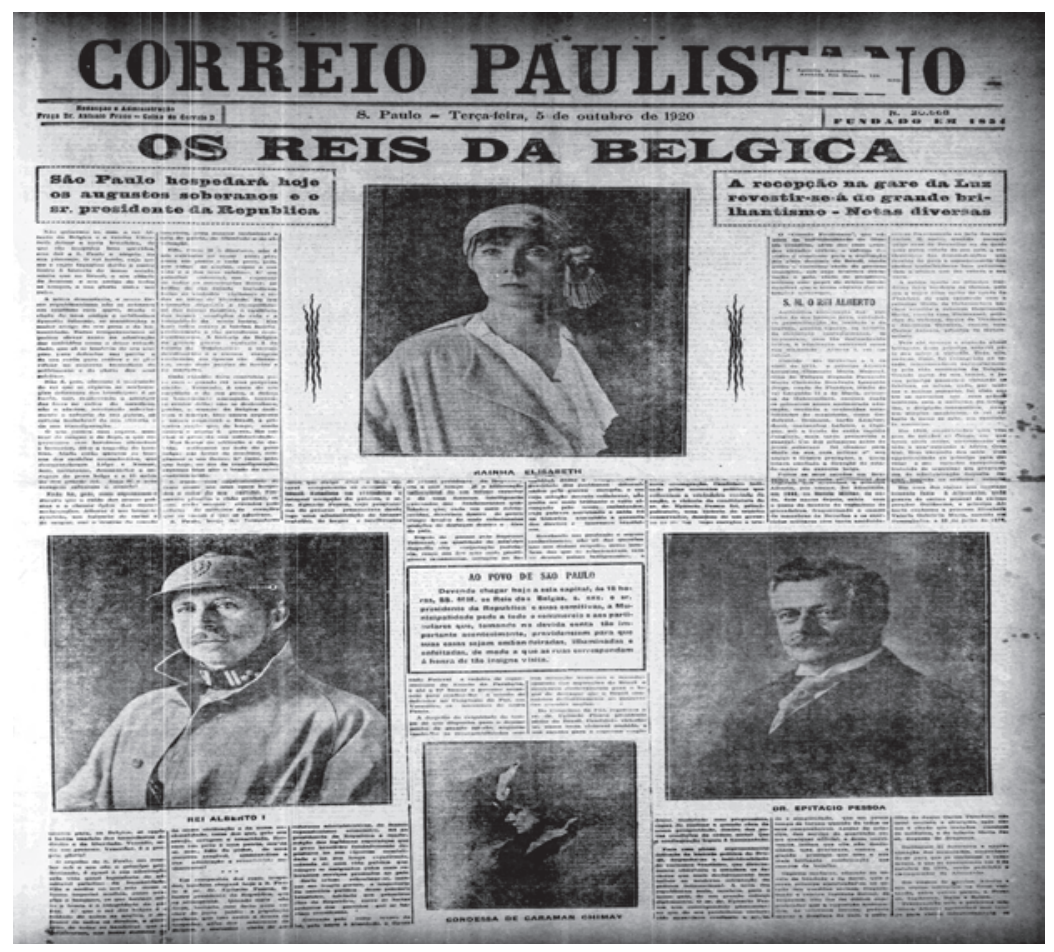

Figura 16: A visita belga na imprensa paulista

Fonte: Correio Paulistano, 05.10.1920

Para o jornal Correio Paulistano, os soberanos não quiseram deixar a terra brasileira sem visitar São Paulo, "berço dos formadores da nossa civilização e da nossa nacionalidade, terra dos que, pelo seu arrojo, coragem e tenacidade, fizeram um povo e uma pátria, saúda ss.mm" (CORREIO PAULISTANO; AGENCIA AMERICANA, 1920). O jornal publica também em suas páginas um comunicado da municipalidade, pedindo que tanto o comércio como particulares providenciassem o embandeiramento de suas residências.

Após longa apresentação do rei, com detalhada biografia, a edição paulista do Jornal do Commercio coloca que São Paulo, "terra heróica das 'bandeiras', que sempre está ao lado das grandes causas”, orgulhosa de sua contribuição por seus recursos econômicos ao prestígio da pátria, saberá se manifestar, "nas ovações de sua população inteira como nas gentilezas e cortesia finíssima do seu Governo" (JORNAL DO COMMERCIO; AGENCIA AMERICANA, 1920). 
No dia 5 de outubro, já perto das oito horas da noite, os soberanos belgas finalmente chegam à Estação da Luz, em São Paulo. Foram executados os hinos nacionais e formado o cortejo em direção a Chácara Carvalho, onde ficaram hospedados.

Sobre a recepção, entusiásticas são as impressões do jornal paulista A Capital:

Vibra de simpatia, de entusiasmo, e de desusada alegria a população paulista, com a mesma perseverança demonstrada pelos seus avós - os bandeirantes! [...] engalanando-se e vibrando de sincero afeto, transborda dessa afeição [...] toda brasileira. [...] São Paulo recebeu-os numa estupenda apoteose em que a alma popular vibrou uníssona e comunicativa, se alastrando pela cidade no mais retumbante coro. [...] Muito embora não houvesse a cidade sofrido reparos materiais que a regia presença determinava, ainda mesmo sem a ornamentação dos postes e combustores, a capital se engalanou com o jubilo sincero e respeitoso de seus habitantes. [...] No Brasil o soberano tem conhecido um povo só. Fortes e unidos, capazes, respeitadores e bons os brasileiros olharam o vulto dos heróis por um só prisma (A CAPITAL; AGENCIA AMERICANA, 1920).

É marcante na citação acima a referência à ancestralidade bandeirante, distinguindo o povo paulista, ao mesmo tempo em que se procura incluí-lo na "alma brasileira", ao vibrar com a presença real, apesar da cerimônia não ter se revestido de elementos para provocar tal participação. Uma observação também colocada pelo Jornal do Commercio, segundo o qual a recepção na cidade preencheu as expectativas, mas "não as excedeu". O fato de a comitiva tomar autos fechados concorreu para uma diminuição na fascinação que o cortejo devia despertar, além do fato da iluminação das ruas por onde devia passar o cortejo não ter sido aumentada, faltando inclusive uma ornamentação festiva. (JORNAL DO COMMERCIO; AGENCIA AMERICANA, 1920)

Mas a população teria oportunidade de saudar o rei durante seus passeios pela cidade, destruindo a "frieza que poderia empanar o brilho dos festejos com que S.Paulo os recebeu em seu território" (CORREIO PAULISTANO; AGENCIA AMERICANA, 1920). Momento em que:

[...] a culta e ilustre capital de um dos mais cultos e ilustres Estados da União soube demonstrar aos augustos itinerantes como fazia causa comum com os demais centros que visitaram, manifestando-lhes, pelas ovações das ruas como pelas gentilezas do Governo, a sua profunda simpatia e admiração (JORNAL DO COMMERCIO; AGENCIA AMERICANA, 1920). 
É perceptível que aclamar freneticamente o rei é uma característica que identifica essa população com o resto da nação. Trata-se de uma causa comum, à qual nem a "frieza" poderia fazer frente.

Através dos jornais aqui citados, fica aparente que apenas tangenciamos uma questão muito mais ampla, ou seja, de que as recepções e viagens pelos estados brasileiros fazem aflorar certas imagens construídas destas localidades, mais ricas nesse sentido para São Paulo do que para Minas. Não fica claro, a princípio, se ocorrem comparações de um cunho mais crítico às grandes recepções nos principais estados brasileiros.

Entretanto, um artigo publicado pelo Correio Paulistano, em 1921, torna difícil considerar-se que a visita dos reis pelo interior não incitou críticas a esta imagem de "nação unida" que a princípio vislumbramos. Segundo Goulart de Andrade, autor do artigo, na capital federal foram oferecidos aos soberanos concertos, discursos e versos, já na capital paulista priorizou-se visita a ginásios e oficinas. No Rio de Janeiro, o povo se dirigia de madrugada à praia para apreciar os exercícios de natação do soberano belga ${ }^{\bigotimes}$, “descuidando prazenteiramente das tarefas diárias, retardando a hora dos afazeres", enquanto que em São Paulo, “os transeuntes descobriram-no; paravam um momento mesmo", mas logo aceleravam o passo, "a fim de recuperar o tempo perdido. Então a majestade não se conteve mais e falou; essa sim, era cidade de gente ocupada [...]" (Apud MOTTA, 1992, p. 96-97). Tal publicação, citada por Marly Motta em seu estudo sobre o centenário da Independência, faz referência justamente à configuração de um regionalismo paulista baseado na legitimação da metrópole bandeirante como cabeça da nação, e na desqualificação do Rio de Janeiro, identificado como responsável pelo atraso, síntese dos males da República falida e corrupta (MOTTA, 1992, p.81).

Uma comparação que pode ajudar nesse sentido está no Jornal do Commércio. Ao comentar a viagem dos soberanos ao interior do estado paulista, coberto de "soberbos cafezais que sempre maravilham estrangeiros", onde podia se obter "a mais forte impressão [...] da riqueza nacional", o jornal ressalta que, se por acaso, a rainha resolvesse, assim como na excursão no interior de Minas, entrar em uma casa para conhecer a família do interior, voltaria à Europa aconselhando a emigração para o estado:

De fato, o adiantado espírito do lavrador paulista depressa compreendeu a necessidade de instalar bem os seus trabalhadores. Eis porque as casas de residência dos colonos oferecem um aspecto tão agradável e próspero [...]. Assim, os augustos hóspedes terão nítida visão do futuro que aguarda 
aquelas famílias que suas majestades encontrarão a trabalhar nos cafezais de terra roxa. (JORNAL DO COMMERCIO; AGENCIA AMERICANA, 1920)

As palavras acima podem ser analisadas como uma tentativa de construir a imagem de São Paulo como o estado determinante para a nação, com sua riqueza representando o futuro próspero da região, através da emigração, fato que impressionaria em muito os reais visitantes. Por outro lado, temos as impressões deixadas pelo Correio da Manhã sobre a visita da rainha à casa mineira:

Nada nos pode ser mais grato do que a observação a atmosfera tranquila, feita de virtudes domésticas e sentimentos de dadivosa hospitalidade, de um modesto casal, que não tivera tempo de se embandeirar e iluminar, ao lhe abrir as portas. O copo de leite e café de que a rainha Elisabeth se serviu naquela mesa tosca, foi de certo saboreado como um dos maiores encantos da viagem. Esse aspecto do Brasil é dos que não se esquecem nunca, e dos que mais nos honram (CORREIO DA MANHÃ, 1920).

É perceptível a alusão às características mais integradoras da nacionalidade, como a simplicidade, a hospitalidade, a modéstia, em contraste com a imagem da 'casa paulista', sinônimo de riqueza, de trabalho e de crescimento proporcionado pelos imigrantes. Essas diferentes impressões, não seriam, contudo, motivo para não se consagrar ao brasileiro uma característica comum que seria, segundo Correio Manhã, "a sua índole hospitaleira”. Mesmo que ainda fossem necessários "séculos de evolução, para se fixar entre nós, um tipo nacional, com traços comuns", observa o jornal, tal característica estaria presente, tanto no brasileiro do norte, como no sul.

Pensar a chegada dos soberanos nas cidades do Rio de Janeiro, Belo Horizonte e São Paulo implica observar o significado dos vários detalhes que compõem esses eventos. Para tal fato, contribui, primeiramente, o tipo de fontes que utilizamos para a realização desse estudo, composta, em sua maioria por jornais cariocas. Considerando que a imprensa não apenas informa seus leitores dos fatos cotidianos, mas também seleciona e constrói os acontecimentos conforme seus interesses (SIQUEIRA, 1994), percebemos que a recepção carioca, tomada por este olhar, recebe uma atenção muito maior, se comparada com as matérias publicadas sobre Minas e São Paulo.

Especialmente sobre a recepção em Minas, onde utilizamos exclusivamente jornais cariocas, as matérias publicadas se atêm apenas à descrição da chegada, fazendo pequenos comentários sobre o público mineiro, como a 
referência a sua aversão às manifestações públicas, o que, todavia, não teria impedido que prestassem homenagens aos soberanos belgas.

Em relação à imprensa e às recepções, um segundo ponto vale ser ressaltado. Mesmo selecionando o que será ou não publicado, sua atuação é limitada por alguns aspectos considerados essenciais para o sucesso desse tipo de ritual, como a decoração do espaço urbano, de certas ruas da cidade a serem percorridas pelo cortejo, e o momento em que este se realizaria (à noite ou de dia). No caso de São Paulo, o fato de a recepção ter ocorrido à noite, com a iluminação e decoração inadequada das ruas, e ter sido o cortejo realizado em autos fechados, contribuiu, segundo a própria imprensa local, para a diminuição do evento em termos de efeito sobre a população. Tais fatores são tão importantes que a própria recepção no Rio de Janeiro, que estava marcada para o dia 18 de setembro, foi adiada para o dia seguinte, pois, se realizada no dia previamente agendado, ocorreria à noite, prejudicando o evento.

Enfim, na recepção na cidade do Rio de Janeiro é perceptível a convergência de vários desses elementos, como a decoração da Avenida Rio Branco com motivos alusivos à união entre Brasil e Bélgica, a chegada do couraçado S.Paulo, por entre salvas de tiros das fortalezas situadas na Baía de Guanabara e sobrevôos de aeroplanos, o desfile do cortejo pelas principais artérias da cidade e, principalmente, o fato de que seria naquela cidade, onde o soberano belga receberia as primeiras aclamações "brasileiras", compactuaram diretamente para que esse evento fosse "lido" pela imprensa como apoteótico, como o grande momento, no qual o povo "brasileiro" prestou as suas mais gloriosas homenagens ao tão prestigiado rei dos belgas.

\section{CONSIDERAÇÕES}

Ao nos debruçarmos sobre o material produzido pela imprensa sobre a visita, procuramos desconstruir o tom apologético que permeia seu discurso, ressaltando que não havia consenso no momento desta sociedade se organizar e se apresentar para este visitante. Tal abordagem justifica-se quando apontamos, logo na introdução, que tais rituais não configuram exclusivamente momentos de consenso e união.

Vários são os exemplos apontados ao longo texto. Sobressaem as críticas em relação à atuação da polícia na recepção no Rio de Janeiro, bem como a ausência de Rui Barbosa, apontados como fatores que influenciaram negativamente a cerimônia, contribuindo para a diminuição de seu caráter apoteótico. Essas questões são compreensíveis quando atentamos para as 
descrições feitas sobre esse público, e que ressaltam seu comportamento exemplar, prova da compreensão pelo mesmo do significado do evento, ao respeitar seus limites de participação. Tal entendimento explicaria também a grande afluência do público aos eventos aqui estudados e a mobilização que proporcionou.

Ao final desta leitura, diria então que um entendimento da visita, e não apenas dos eventos aqui estudados, encontre-se muito além de se considerar apenas o dissenso ou o consenso que aflora em suas descrições. Talvez tal compreensão encontra-se em apontar para níveis de percepção diferenciados sobre um mesmo evento, onde, por exemplo, as representações do público que ocupou as ruas da capital federal para a recepção dos soberanos demonstram algumas segmentações presentes na própria sociedade e dramatizadas naquele momento específico. Nesse sentido, o próprio regionalismo que aparece nas descrições das visitas a São Paulo e a Minas Gerais é diluído no contexto da visita, não desaparece, mas sofre inflexões, pois aclamar os soberanos belgas torna-se uma fator integrador destas regiões com a nação brasileira.

Enfim, a afluência do público para ver o rei Alberto perpassa essa 'majestade construída' em torno desse personagem, conjugando-se a fatores outros, como a fabricação de uma atmosfera festiva que foge do comum, do ordinário e que leva à participação nessa experiência permeada pelo maravilhoso.

\section{Rituals and Symbols of Power in the Belgian Kings Visit to Brazil, 1920}

Aвstract: This study aims to examine some moments of the visit of the kings of Belgium to Brazil in the year 1920, they are: the period before the arrival of the kings and the receptions in the cities of Rio de Janeiro, Belo Horizonte and Sao Paulo. The choice of these moments is explained by the broad participation of the public on these occasions. Through the descriptions published in the press, and also with the images that appeared with them, we analyze the representations and symbols of power associated to the royal visitors and to the Brazilian Republic.

Keywords: Visit, Belgium Kings, First Republic.

\section{NOTAS}

1 Para o estudo da visita belga foi utilizada a documentação referente ao evento que consta do Arquivo do Itamaraty, e que acabar os telegramas trocados entre 
o Ministro das Relações Exteriores brasileira do momento, Azevedo Marques e o representante brasileiro na Bélgica, Barros Moreira, além da documentação produzida pela comissão organizada para a preparação do evento, chefiada por Azevedo Marques. Arquivo 'Visita dos Reis da Bélgica'. L206 maço 3594; Ofícios da Legação Brasileira em Bruxelas. Arquivo Histórico do Palácio do Itamaraty Estante 205, prateleira um, volume 06.

2 Foram pesquisados os jornais:Correio da Manhã, Jornal do Brasil, A Noite, e O Paiz. Também foram acrescentados artigos de outros jornais que constam do álbum produzido pela Agencia Americana sobre a visita Agencia Americana. Telegramas e noticias sobre a visita de S. S. M. M. os reis dos Belgas ao Brasil, publicadas em setembro de 1920, sendo Presidente da Republica e Exme. Snr. Dr. Epitácio Pessoa. Homenagem da Agencia Americana. Rio de Janeiro: 1920.

3 A utilização das bandeiras belgas e brasileira será amplamente difundida durante a visita, utilizadas principalmente na decoração da cidade, demonstrando a união das sociedades belga e brasileira solidificada pela visita (FIRTH, 1973).

4 Quando da chegada do rei Alberto e rainha Elisabeth, Rui Barbosa, já com a saúde debilitada, havia se retirado para a cidade mineira de Palmira para se recuperar. Todavia, como o senador paraibano havia concorrido com Epitácio Pessoa na última eleição, o governo foi acusado de excluí-lo propositalmente das cerimônias em homenagem aos reis belgas. O encontro de Rui Barbosa com o rei Alberto realizou-se no Rio de Janeiro, no penúltimo dia da estadia dos soberanos belgas no Brasil (FAGUNDES, 2007, p. 219-223).

5 A escolha de Epitácio Pessoa ocorreu justamente devido à ausência de um acordo entre as principais oligarquias, somente um candidato neutro, ou seja, proveniente de um estado como a Paraíba, com influência política, poderia ocupar o cargo. Sobre o processo político partidário na Primeira República ver: VISCARDI, 2001.

6 Durante sua permanência na capital, o rei Alberto e também a rainha Elisabeth tomaram frequentes banhos de mar na praia de Copacabana (FAGUNDES, 2007).

\section{REFERÊNCIAS}

AGENCIA Americana. Telegramas e noticias sobre a visita de S. S. M. M. os reis dos Belgas ao Brasil, publicadas em setembro de 1920, sendo Presidente da Republica e Exme. Snr. Dr. Epitácio Pessoa. Homenagem da Agencia Americana. Rio de Janeiro: 1920.

ARQUIVO 'Visita dos Reis da Bélgica'. Arquivo Histórico do Palácio do Itamaraty. L206 maço 3594.

BIRBAUM, Norman. Monarchs and sociologists: a reply to professor Shils ans Mr. 
Young. Sociological Reviem, v.111, n.1, p. 5-23, 1955.

BLOCH, Marc. Os reis taumaturgos: o caráter sobrenatural do poder régio, França e Inglaterra. São Paulo: Companhia das Letras, 1993.

BURKE, Peter. A fabricação do rei: a construção da figura pública de Luís XIV. Rio de Janeiro: J. Zahar, 1994.

CAUFIELD, Suenn. Em defesa da honra: moralidade, modernidade e nação no Rio de Janeiro (1918-1940). Campinas: Ed. da Unicamp; Centro de Pesquisa em História Social da Cultura, 2000.

DI MAMBRO, Galba. As relações belgo-brasileiras: 1830-1921. Juiz de Fora: Revista Eletrônica de História do Brasil, UFJF, v. 4,n. 1, jan./jun. 2000. Disponível em: <http:// www.rehb.uff.br/anteriores/v4n1/41galba.htm>. Acesso em: 30 set. 2006.

DIÁRIO do Congresso Nacional. Disponível em: <http://imagem.camara.gov.br/ diarios.asp>. Acesso em: 26 set. 2006.

DURKHEIM, Émile. Os ritos representativos ou comemorativos. In: . Asformas elementares da vida religiosa. São Paulo: M. Fontes, 2000.

FAGUNDES, Luciana Pessanha. Uma República em festa: a visita dos reis da Bélgica ao Brasil (1920). Dissertação (Mestrado) - UFRJ/PPGHIS, Rio de Janeiro, 2007.

FERREIRA, Marieta de Morais. A nova velha História: o retorno da história política. Estudos Históricos, Rio de Janeiro, v. 5, n. 10, p. 265-271, 1992.

FIRTH, Raymond. Symbols - public and private. London: George Allen; Unwin, 1973.

GEERTZ, Clifford. O saber local: novos ensaios em antropologia interpretativa. Petrópolis: Vozes, 1997.

JORNAL A Noite, Rio de Janeiro, 1920.

JORNAL do Brasil, Rio de Janeiro, 1920.

JORNAL O Paiz, Rio de Janeiro, 1920.

JORNAL, Correio da Manhã, Rio de Janeiro, 1920.

LE GOFF, Jacques. et al. A política será ainda a ossatura da História? In: LE GOFF, J. O maravilhoso e o quotidiano no Ocidente medieval. Lisboa: Edições 70, [s.d.].

LUKES, Steven. Political ritual and social integration. Sociology, 9, p. 289-308, 1975. MOTTA, Marly da Silva. A Nação faz 100 anos. A questão nacional no Centenário da Independência. Rio de Janeiro: Ed. da FGV; CPDOC, 1992.

Ofícios da Legação Brasileira em Bruxelas. Arquivo Histórico do Palácio do Itamaraty Estante 205, prateleira um, volume 06.

RÉMOND, René. (Org.). Por uma história política. 2. ed. Rio de Janeiro: Ed. da FGV, 2003.

SCHWARCZ, Lilia Moritz. As barbas do imperador: D. Pedro II, um monarca nos 
trópicos. 2. ed. São Paulo: Companhia das Letras, 1999.

SHILS, Edward; YOUNG, Michael. O significado da coroação. In: SHILS, Edward. Centro e periferia. Lisboa: Difel, 1992.

SILVA, Lígia Osório. A crise política no quadriênio Bernardes: repercussões políticas do "caso da Itabira Iron". In: LORENZO, Helena Carvalho; COSTA, Wilma Peres (Org.). A década de 20 e as origens do Brasil moderno. São Paulo: Edunesp, 1997.

VISCARDI, Claudia Maria Ribeiro. O teatro das oligarquias: uma revisão da política do 'café com leite'. Belo Horizonte: C/A, 2001. 